This Section of Epidemiology and Psychiatric Sciences appears in each issue of the Journal and is dedicated to all forms of creative production born of an intimate and individual urge, often secretive, unbound from the conventional art system rules. Through short descriptions of the Outsider art work of prominent artists and new protagonists often hosted in community mental health services, this Section intends to investigate the latest developments of the contemporary art scene, where the distances between the edge and the center are becoming more and more vague.

Carole Tansella, Section Editor

\title{
The art \& life of Gerald Hawkes
}

\section{R. Hoffberger}

American Visionary Art Museum, Baltimore, Maryland, USA

Received 22 July 2014; Accepted 10 October 2014; First published online 19 November 2014

Key words: American Visionary Art Museum, intuitive self-taught genius, Outsider art, matchstick wonders.
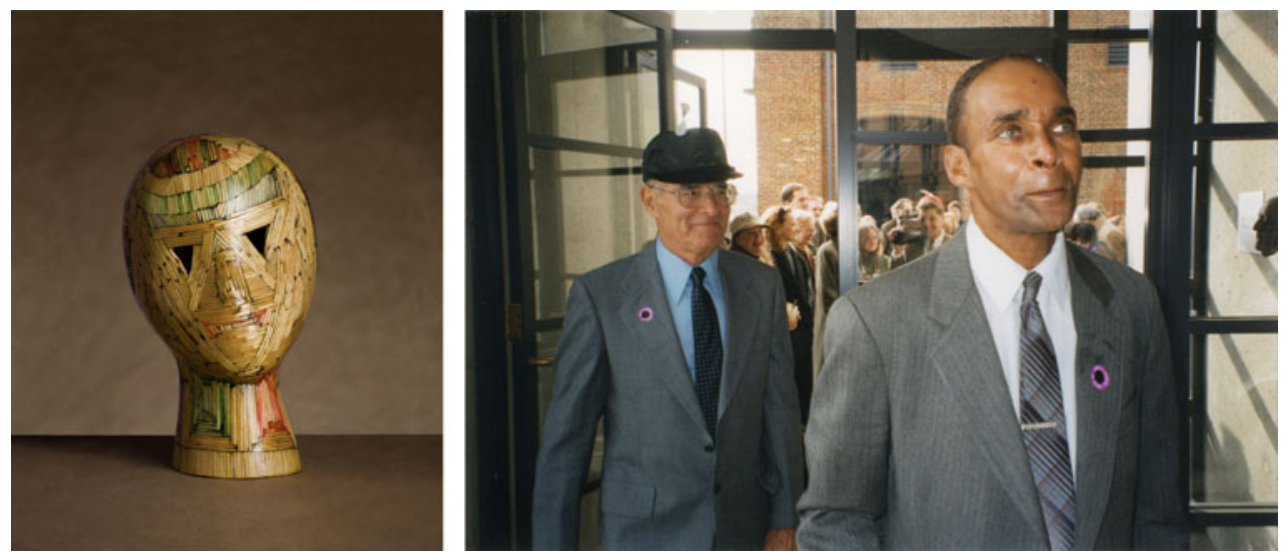

On the left: Gerald Hawkes, My Beccy, Woman Of The Year, 1993 matchsticks, food dye, glue, polyurethane paint, Permanent Collection of the American Visionary Art Museum, photo by Dan Meyers.

On the right: Visionary artists Gerald Hawkes and Vollis Simpson are first to walk through AVAM's doors on opening day, November 24, 1995. Photo by LeRoy Hoffberger.

Many of us are fans of the 1966, cult classic film, 'The King of Hearts.' It artfully begs the question, 'In a world addicted to war, who among us is truly sane?'

When I first conceived of the idea of founding the American Visionary Art Museum devoted to the creative power of self-tutored vision and intuition, I

\footnotetext{
*Address for correspondence: Hon. D. A. Rebecca Hoffberger, American Visionary Art Museum, 800 Key Highway Baltimore, Maryland 21230, USA.

(Email: rebeccavisionary@gmail.com)
}

was employed by the Department of Psychiatry at Sinai Hospital as the development director for a large psycho-social programme that taught life and job re-entry skills to people with histories of chronic mental illness. I met Gerald Hawkes, who was in a nearby Veterans Hospital, branded, post a horrific mugging with various psychiatric diagnoses and brain damage. Gerald had managed to sufficiently charm his nurses with his personality and matchstick sculptures that they enthusiastically brought him to my attention. Gerald was African American, with strange, luminous 
blue green eyes, a deep spirituality, a ready smile and a heroin habit that kicked in only after the attack by unknown assailants caused him to lose his health, his marriage, his employment, and his sense of smell and taste. Newly homeless and on the streets after a lifetime of solid middle class comfort, Gerald concluded, 'I didn't want to hate for the rest of my life. I began making matchstick sculptures because people are like matchsticks in that we all have the ability to give light - or not.' A deeply symbolic thinker with a penchant for math, geometry and the Bible, Gerald produced a wide variety of intricate matchstick sculptures, soaking them to allow the matchsticks to curve without breaking, dying them in symbolic colours. 'Colors are very important. I use blue - for peace in the sky. Green for life, earth living and growth. Yellow means shine, bright with energy. Orange is lighting the midnight hour. Natural, the beginning of all color. Red, exact and hot, hot, more hot.'

Gerald sold and exhibited his works widely, some selling for thousands of dollars. He gave away most of the money in days, never remembering to pay his taxes. I twice had to go to court to keep him from being sentenced to jail for tax evasion. On the Opening Day of our American Visionary Art Museum, Thanksgiving Weekend of 1995, Gerald Hawkes was the very first person to walk through our front doors, followed by farmer and master whirligig maker, Vollis Simpson. Hawkes was at times a rascal, manipulative, unreliable, but always a very original thinker. He could be totally self-centred or extraordinarily and genuinely caring. When the dirty street needles he used imparted the HIV virus and eventually hastened his death, the respect and affection that people from a wide variety of our Baltimore community, and far beyond, inspired them to come in droves to help spread Gerald's ashes in our national museum's wildflower garden to pay their tribute. His service took place on a windy day and we all felt we swallowed at least an ounce of powdered Gerald. His little nieces ran laughing in the garden as we lit and held long stick matches, intoned prayers from the three major faiths, and learned that even when people disappoint you, you can still love them. Our American Visionary Art Museum has the largest collection of Gerald Hawkes matchstick works. They are proudly on permanent display, alongside his wisdoms. Among the most beloved of his teachings:

' $\mathrm{I}$ 'd rather do art than eat. I use it as medicine. I use it for self-motivation. I ask God to decrease me and increase Him. Put me in a world where it's just Him and I.'

'Rearrange the letters in AMERICA. They can spell out, "I AM RACE." I prefer "US". It can really stand for "Unity and Strength" for all people of all races. It is here that we got to learn to love one another as one.'

'You take a match and you burn the end. You save the rest and you die it - maybe with grapes or coffee grounds. Later, you glue the matches together. Nineteen matches side by side make a square.'

Gerald even provided his personal review of our one-of-a-kind American Visionary Art Museum. He explained, 'The difference between the Visionary Art Museum and most other museums is the letter " 1 " and " $\mathrm{d}$ ". Most museums are founded on "Readity" housing things you can look up in books and reference in libraries. The American Visionary Art Museum is based on Reality - the art made by people out of their real lives, their real dreams and visions.'

Flawed as are we all, Gerald Hawkes remains one of the most exquisitely unforgettable people I ever knew, transcending in my book labels of any kind.

\section{Acknowledgements}

None.

Financial Support

None.

\section{Conflict of Interest}

None.

\section{Supplementary materials and methods}

The supplementary material referred to in this article can be found at http://www.journals.cambridge.org/EPS

\section{Reference}

Hoffberger R, Manley R, Wilson C (1997). Tree of Life: the Inaugural Exhibition of the American Visionary Art Museum, AVAM: Baltimore.

\section{About the Author}

Rebecca Hoffberger, Hon. D. A., is founder and Director of the American Visionary Art Museum (AVAM) in Baltimore, MD, America's official national museum and education center for intuitive, self-taught artistry. Since its opening in 1995, the museum has sought to promote the recognition of intuitive, selfreliant, creative contribution as both an important 
historic and essential living piece of treasured human legacy. AVAM is located in downtown Baltimore's Inner Harbor area, adjacent to historic Federal Hill park. Three renovated, historic industrial buildings house wonders created by farmers, housewives, mechanics, retired folk, the disabled, the homeless, as well as the occasional neurosurgeon-all inspired by the fire within. From carved roots to embroidered rags, tattoos to toothpicks, "The Visionary" transforms dreams, loss, hopes, and ideals into powerful works of art.
AVAM has a permanent collection of nearly 5,000 pieces and mounts one grand thematic exhibition each year that lasts for 11 months. This year's exhibit, "The Visionary Experience: Saint Francis to Finster," features over 40 visionary artists, scientists, inventors, and spiritual pioneers. Hoffberger's foresight and daring passion for intuitive artistry has helped to create a space in the art world that preserves, educates, and promotes the study of visionary and outsider art.

Carole Tansella, Section Editor 